\title{
Monitoring and Managerial Discretion Effects on Agency Costs: Evidence from an Emerging Economy
}

\author{
Jorge Andrés Muñoz Mendoza ${ }^{1}$ \\ Sandra María Sepúlveda Yelpo ${ }^{1}$ \\ Carmen Lissette Veloso Ramos ${ }^{1}$ \\ Carlos Leandro Delgado Fuentealba ${ }^{2}$ \\ ${ }^{1}$ Universidad de Concepción, Los Ángeles, Bío-Bio, Chile. \\ ${ }^{2}$ Universidad de Concepción, Chillán, Nuble, Chile.
}

Received 13 September 2019. This paper was with the authors for two revisions. Accepted 22 April 2021. First published online 20 May 2021.

Editor-in-chief: Carlo Gabriel Porto Bellini @ (Universidade Federal da Paraiba, João Pessoa, PB, Brazil) Associate editor: Josete Florêncio dos Santos (Universidade Federal de Pernambuco, Recife, PE, Brazil), Gustavo Alfonso Barrera Verdugo (Universidad de Las Américas, Chile)

Reviewers: Antonio Zoratto Sanvicente (Fundação Getulio Vargas, São Paulo, SP, Brazil), and two anonymous reviewers

Editorial assistants: Kler Godoy and Simone Rafael (ANPAD, Maringá, PR, Brazil) 


\begin{abstract}
We analyzed the effect of managerial ownership, leverage, and managerial discretion on the agency costs of 14,719 Chilean companies. The results of the instrumental variables (IV) regressions indicate that managerial ownership and capital structure have a negative and nonlinear effect on agency costs. Managerial ownership concentration is an effective means of internal control over agency costs, discarding the managerial entrenchment effect. The non-linear impact of debt suggests that for high leverage levels, agency costs would increase due to higher bankruptcy costs. Managerial discretion reduces agency costs; however, in firms with low growth opportunities, it increases them. These results have relevant implications for firms' corporate policy and investors.
\end{abstract}

Keywords: agency costs; managerial discretion; monitoring; growth opportunities

JEL Code: G30, G32, G34 


\section{INTRODUCTION}

Conflicts between company owners and managers can generate costs that affect firms and investor wealth. International evidence shows that agency costs are recurrent in large firms with diluted ownership structures (Ang, Cole, \& Lin, 2000; Gogineni, Linn, \& Yadav, 2016; Jensen \& Mecking, 1976; Katti \& Raithatha, 2018), low debt, mainly long-term debt (Alderson \& Betker, 2003; Morellec, 2004), and greater information asymmetries (Ross, 1977). All these studies have concluded that agency costs are determined by the influence of internal and external factors.

From an internal point of view, managerial ownership is one of the main means of corporate control. Several seminal studies in this area have shown that the managerial ownership concentration reduces agency costs because it mitigates incentives for underinvestment and imposes corporate restrictions on managers (Fleming, Heaney, \& McCosker, 2005; Gogineni et al., 2016; Jensen \& Meckling, 1976; Shleifer \& Vishny, 1997; Stulz, 1990). However, other studies have indicated a contrary point of view, that the excessive concentration of managerial ownership can lead administrators to entrench their management and avoid corporate control. This entrenchment effect would increase agency costs (Berger, Ofek, \& Yermack, 1997; De Angelo \& De Angelo, 1985). From an external point of view, leverage is one of the main means of corporate control, and empirical studies show a situation similar to that of managerial ownership. Several studies have validated the control hypothesis associated with leverage (Berger et al., 1997; Fleming et al., 2005; Jensen, 1986; Li \& Cui, 2003). According to these researches, debt exercises an external means of supervision that disciplines managers and inhibits the discretionary use of investment policy. Other studies warn that, while leverage mitigates equity agency costs, excessive indebtedness would lead to an increase in debt agency costs, mainly those related to bankruptcy costs (Jensen \& Meckling, 1976; Rashid, Khidmat, Al Hares, Muhammad, \& Saleem, 2020; Zhang \& Li, 2008; Zhang, Tang, \& Lin, 2016).

The debate on the effects of managerial ownership and leverage is still open, and in the case of Chile it is even more so. Chile, like other Latin American countries, has an institutional regime that offers low protection for investors' rights, and companies have a high ownership concentration and less use of debt compared to other emerging markets (Booth, Aivazian, Demirgüc-Kunt, \& Maksimovic, 2001; Hai, Min, \& Barth, 2018; Khan, Mihret, \& Muttakin, 2016). These qualities create a conductive space for higher agency costs that have not been researched yet. Furthermore, discretion of managers can also be another relevant factor on agency costs. More recent studies indicate that managers' behavior conveys a signal about their business management skills (Miller, 2011). The control exercised by the managers' labor market would lead them to act aligned with owners' interests (Fama, 1980). However, when firms operate with lower growth opportunities, managers would take advantage of information asymmetries to act in a discretionary manner and hide their behavior within the randomness of firm's performance (Diamond \& Verrecchia, 1982). This relationship on agency costs has not been researched for the Chilean market either.

Therefore, the aim of this research is to determine the impact of managerial ownership, leverage, and managerial discretion on the agency costs of Chilean firms. The empirical contributions of 
this research are summarized in three points. First, we analyzed a possible non-linear, U-shaped impact of managerial ownership on agency costs. Based on empirical debates, we believe that the level of managerial ownership is relevant to assess its impact on agency costs. If the relationship were non-linear, then the impact of managerial ownership on those costs would establish a tradeoff between the effects of control and managerial entrenchment. Second, we studied a possible non-linear, U-shaped impact of leverage on agency costs. At this point, our hypothesis indicates that the effect of leverage on agency costs establishes a trade-off between the control effect on investment policy and debt agency costs. Finally, we analyzed the impact of management discretion on agency costs and how its effect is conditioned by the company's growth opportunities. Answering these questions is relevant for the Chilean market and even for other emerging countries with similar structural qualities, as it would provide evidence for the design of means of corporate control based on the ownership and financing structure, as well as for implementing regulations that strengthen corporate governments.

We used a sample of 14,719 firms extracted from the Longitudinal Business Survey (LBS). Sample characteristics also reinforce the empirical contribution of this study, as companies have different ownership structures. Companies with a total ownership concentration in the owner/manager and firms with diluted ownership or with low managerial ownership were particularly significant. These features differ from previous studies in Chile and allow us to evaluate the principal-agent problem. Our results indicate that managerial ownership and capital structure have a negative and non-linear effect on agency costs, suggesting that managerial ownership concentration is an effective internal control means over agency costs, discarding the entrenchment effect. Additionally, the non-linear impact of debt suggests that for high leverage levels, agency costs would increase due to higher bankruptcy costs. Managerial discretion reduces agency costs, but increases them for firms with low growth opportunities. These findings have important implications for companies and investors in the Chilean market or similar emerging economies. For firms, our results allow them to infer the effectiveness of the control means on agency costs according to the level of managerial ownership and leverage. Even according to their growth opportunities, they could also infer potential managers' opportunistic behaviors. This information is also relevant for investors, as it helps them improve their investment decisions.

This article is divided into five sections. The literature review on the determinants of agency costs follows this introduction along with the research hypotheses. Section 3 presents the variables and the statistical and econometric methodology, while Section 4 illustrates the main results. Finally, Section 5 presents the main conclusions of this research.

\section{THEORETICAL FRAMEWORK AND HYPOTHESES}

\section{Ownership structure as internal monitoring mechanism}

Ownership structure is a means of internal control on agency costs. Jensen and Meckling (1976) point out that agency costs are made up of agency costs of equity and debt. Equity agency costs arise when corporate control and ownership are separated. Therefore, firms with diluted

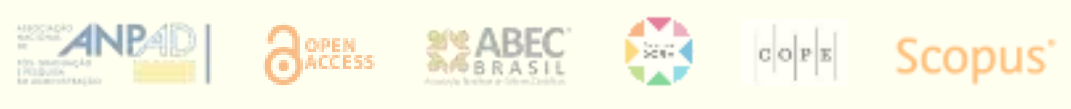


ownership or with greater information asymmetries allow managers to act in their own interests and to hide this behavior into randomness of the firm's performance. These conditions generate higher agency costs (Berle \& Means, 1932; Diamond \& Verrecchia, 1982; Ross, 1977).

Although some literature argues that outside managers or managers with low ownership participation still work according to profit maximization (Demsetz, 1983; Demsetz \& Villalonga, 2001), most empirical studies support that higher managerial ownership reduces equity agency costs, and therefore reduces total agency costs. In developed markets, the role of ownership structure on agency costs is more relevant due to the lower degree of ownership concentration and structural differences in relation to emerging markets (Iatridis, 2012). Ang, Cole, and Lin (2000) analyzed the agency costs for 1,708 small businesses from the US National Survey of Small Business Finances (NSSBF). Their results indicate that agency costs are significantly lower when managerial ownership is higher and corporate ownership is concentrated. Florackis (2008) analyzed agency costs for 897 firms in the United Kingdom and showed that ownership dilution and lower managerial ownership lead to higher agency costs. More recently, Gogineni, Linn, and Yadav (2016) analyzed firms for the Irish and UK markets between 2005 and 2009. Their findings confirm that agency costs increase in firms with diluted and organizationally more complex ownership structures. Even managerial ownership is a relevant means of control over these costs. Other studies support these results and agree that higher managerial ownership is an effective internal mechanism to mitigate agency costs and promote operational efficiency (Stulz, 1990; Shleifer \& Vishny, 1997; Denis \& McConnell, 2003; Singh \& Davidson, 2003; Fleming et al., 2005; Florackis \& Ozkan, 2009; Hastori, Siregar, Sembel, \& Maulana, 2015; Gogineni et al., 2016; Ruiqi, Wang, Xu, \& Yuan, 2017; Aktas, Andreou, Karasamani, \& Phillip, 2019; Schäuble, 2019). However, there are studies that have shown an opposite result, opening an empirical debate on the effects of managerial ownership on agency costs. These studies reveal that excessive concentration of managerial ownership could increase agency costs because managers would entrench corporate management to avoid monitoring (Berger et al., 1997; De Angelo \& De Angelo, 1985). This fact is known as the managerial entrenchment hypothesis, and it considers that managers with greater managerial ownership obtain benefits by arbitrating the value of their assets to the detriment of the firm's value. This controversy has not been researched and suggests that the level of managerial ownership is crucial to evaluate its impact on agency costs.

In emerging markets, firms are characterized by having pyramidal and highly concentrated ownership structures, an aspect that differs from developed markets (La Porta, Lopez de Silanes, \& Shleifer, 1999). Despite this, empirical evidence shows similar findings for both markets. Harvey, Lins, and Roper (2001) analyzed 1,132 firms from 18 emerging markets and showed that ownership concentration mitigates agency costs and creates value for shareholders. Katti and Raithatha (2018) studied Indian firms and indicated that greater managerial ownership is a concentration mechanism that controls agency costs. This way of control generates an increase in the operational efficiency and performance of the firms (Borlea, Achim, \& Mare, 2017; Ruiqi et al., 2017). More recently, Rashid, Khidmat, Al Hares, Muhammad, and Saleem (2020) studied Chinese companies and also showed that ownership concentration increases the quality of corporate governance and through it, agency costs decrease. Hai, Min, and Barth (2018) even add that foreign ownership has increased in emerging markets. This fact has reinforced the control 
effect of the ownership structure and has alleviated the pressures of the political environment associated with state ownership. In Chile, some studies have implicitly corroborated that the concentration of managerial ownership reduces agency costs. Paredes and Flor (1993) indicate that companies listed on the stock exchange have ownership structures consistent with profit maximization even when the manager is an outsider. Lefort and Walker (2007) point out that in Chilean companies listed on the stock exchange, the ownership concentration is strongly correlated with the control of the company. They add that such concentration is a protection mechanism developed by investors because Chile has a low level of legal protection for them. However, studies for emerging markets have not tested the managerial entrenchment hypothesis. Chile, as other emerging markets, has similar qualities to other emerging countries and when this relationship is studied, its implications can be extrapolated to other countries for the design of managerial control mechanisms and regulations that strengthen corporate governments.

We believe that the lack of empirical consensus regarding the effects of managerial ownership on agency costs is due to a possible non-linear and U-shaped relationship. This type of relationship would imply that the level of managerial ownership would be relevant to its effect on agency costs, and would generate a trade-off between the effects of corporate control and managerial entrenchment. If so, this type of relationship would have relevant implications for corporate governance and supervision mechanisms of Chilean firms. Therefore, we formulate our first hypothesis:

H1: Managerial ownership has a non-linear effect (U-shaped) on agency costs.

\section{Capital structure as external monitoring mechanism}

Capital structure is an external factor that also affects agency costs. Jensen (1986) proposes that firms issue debt to discipline managers. Debt acts as a mechanism that exposes management to external funders and gives debt payment a higher priority in relation to the discretionary use of flows for overinvestment. International evidence has corroborated that firms must issue a higher level of debt (Berger et al., 1997; Fleming et al., 2005; Li \& Cui, 2003; Park, 2000; Rakesh \& Lakshmi, 2013) or maintain more extensive business relationships with external funders to reduce agency costs and increase operational performance (Ang et al., 2000; Fleming et al., 2005; Sass \& Gisser, 1989). Nevertheless, Jensen and Mecking (1976) and Ross (1977) point out that the dissuasive effect of debt on agency costs is not persistent. This would be explained by the progressive increase of debt agency costs, specifically bankruptcy costs. For this reason, Zhang and $\mathrm{Li}$ (2008) suggest that the effect of debt on agency costs is U-shaped. They add that the deterrent effect of debt cannot be prolonged over time, especially if the debt level is high enough. In this case, the debt control effect would vanish due to the higher bankruptcy costs after a threshold capital structure that minimizes agency costs. This second effect is driven by the debt agency costs indicated by Smith and Warner (1979), which increase the bankruptcy probability and the firm's liquidity risk. In general, empirical evidence for developed and emerging markets has supported the hypothesis of debt control over agency costs. However, the most recent evidence warns that borrowing increases agency costs (Ang et al., 2000; Fleming et al., 2005; Rakesh \& Lakshmi,

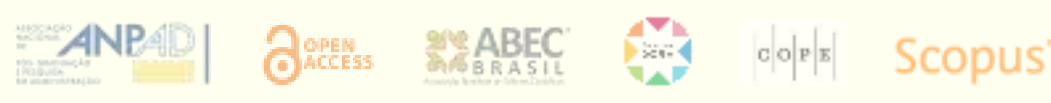


2013). Pandey and Sahu (2019), in a study carried out in Indian firms between 2009 and 2016, concluded that leverage increases agency costs due to the presence of higher bankruptcy costs. Even these costs reduce the firm's performance.

Latin American firms have been characterized by low levels of indebtedness (Booth et al., 2001). Recently, De Gregorio, García, and Jara-Bertin (2017) warned that after the 2008 financial crisis, firms in the region increase their leverage due to its low cost. This may mean that the debt control effect would be marginally reduced. In Chile, there are no studies that have directly analyzed the effect of debt on agency costs. However, other studies have examined factors such as firm's performance and dividend policy, and have indirectly concluded that financing policy is an effective control mechanism that mitigates agency costs and improves corporate performance (De Andrés, San Martín, \& Saona, 2004; Maquieira \& Danús, 1998; Maquieira \& Moncayo, 2004). A possible non-linear effect of debt on agency costs would validate the existence of a trade-off between the control effect hypothesis and debt agency costs. These effects are associated with the debt level. If so, such a finding would be relevant to the capital structure decision of Chilean companies and other emerging markets, leading us to the following hypothesis:

H2: Corporate debt has a non-linear effect (U-shaped) on agency costs.

\section{Managerial discretion and agency costs}

Managerial discretion can have relevant effects on agency costs. Various studies reveal the importance of managers' conduct as a sign of their ability to manage the firm. Such a signal would not only transmit credibility to various stockholders, it would also show the degree of discretion involved in decision-making by managers (Hayibor, Agle, Sears, Sonnenfeld, \& Ward, 2011; Stanwick \& Stanwick, 2003; Wade, Porac, Pollock, \& Graffin, 2006; 2008). Katti and Raithatha (2018) reveal that managers play a relevant role on agency costs. Zhang, Tang, and Lin (2016) add that the manager's discretion can generate agency costs, especially if managerial compensation is low and the means of corporate control are weak.

Managerial discretion corresponds to opportunistic behaviors of managers, which are aimed at increasing their own well-being, even if this implies a loss of the firm's value or the wealth of the investors. Few studies have analyzed the impact of managerial discretion on agency costs and there is no consensus on this matter. Miller (2011) argues that managers act at their discretion when they take advantage of information asymmetry and the ineffectiveness of corporate means of control, both internal and external. This behavior generates higher agency costs. The weakening of internal and external control means is associated with ownership dilution and lower debt level, respectively (Berle \& Means, 1932; Jensen \& Meckling, 1976; Park, 2000). Diamond and Verrecchia (1982) add that information asymmetries could accentuate the weakening of internal and external control means. This fact would allow managers to hide their discretionary behavior and generate higher agency costs (Ross, 1977). Stanwick and Stanwick (2003) and Wade, Porac, Pollock, and Graffin $(2006 ; 2008)$ also point out that if managers develop these discretionary behaviors, the firms' corporate efficiency is reduced due to increased agency costs. 
However, when corporate control means are effective, managers' discretionary behavior is negatively correlated with agency costs. Morck, Shleifer, and Vishny (1989) point out that the supervision from the company's investors (minority shareholders, bondholders, or banks) leads managers to act more in line with corporate interests, increases the company's performance, and reduces agency costs. Shleifer and Vishny (1997), Denis and McConell (2003), and Balkin (2008) point out that the owners and the board of directors of the company are able to act as an internal means of monitoring that disciplines administrators and mitigates their discretional behavior. Fama (1980) also adds that the managers' labor market is a means of external control over managerial discretion, as managerial compensation is a function of the historical performance and marginal productivity expectations of the manager. These aspects would lead managers to act in line with the owners' interests.

The impact of managerial discretion on agency costs has not been researched in the Chilean market. In Chile, characteristics of corporate ownership and institutional qualities would make managers align with the owners' interests. In companies listed on the stock exchange, managers are appointed by controlling shareholders, while in smaller firms, managers own part of the business ownership. According to these qualities, we believe that managerial discretion is negatively correlated with agency costs. This leads us to formulate our third hypothesis:

H3: Managerial discretion has a negative effect on agency costs.

The impact of managerial discretion on agency costs depends on firms' growth opportunities (Jensen, 1986). Diamond and Verrecchia (1982) warn that managers take advantage of information asymmetries to hide their discretionary behaviors within the randomness of corporate performance. This also coincides with a lower effectiveness of the company's internal and external means of supervision, and less growth opportunities (D'Mello \& Miranda, 2010; Lang, Paulsen, \& Stulz, 1995). When firms present low growth opportunities, managers can develop behaviors that are not aligned with the owners' purposes and thus increase agency problems. This leads us to formulate our fourth hypothesis:

H4: In firms with low growth opportunities, managerial discretion has a positive effect on agency costs.

\section{DATA AND METHODS}

\section{Data sample}

Data were obtained from the Longitudinal Business Survey (LBS), performed by the Ministry of Economy, Development, and Tourism of Chile. Surveys were published in versions 1 (LBS1), 2 (LBS2), and 3 (LBS3), and contain qualitative and quantitative information on Chilean firms for 2007, 2009, and 2013, respectively. The aim of this survey is to characterize the country's companies according to their size and economic activity, in order to identify the determinants of enterprise development. We compiled a pooled database for 14,719 public and non-public

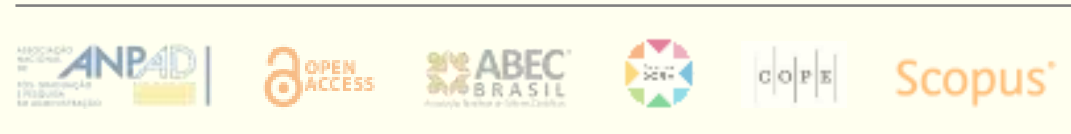


companies, distributed across 6,647 (LBS1), 3,882 (LBS2), and 4,190 companies (LBS3). Firms with incomplete records and those in the financial intermediation sector were eliminated.

The LBS provides a representative sample of firms in terms of size and organizational structures, which have not been used for empirical studies. According to Table 1, the total sample of all three versions of the LBS is distributed in 2,697 large (18.32\% of the sample), 2,096 medium (14.24\%), 3,881 small (26.37\%), and 6,045 micro (41.07\%) companies. Large companies are mainly closed corporations whose ownership and corporate control are separated, while micro and small companies are structured mainly as limited liability companies or natural person companies. In these firms, it is possible to observe a total ownership concentration in the manager. In addition, almost two thirds of the sample is concentrated in four economic sectors: wholesale/retail trade (31\%), real estate activities (14\%), manufacturing $(11 \%)$, and agriculture, forestry, and livestock activities (9\%).

The LBS provided information related to firms' accounting, finance, and management. It is important to note that the LBS does not provide market information. Table 2 presents the variables.

Table 1

Sample of company composition

\begin{tabular}{|c|c|c|c|c|c|c|c|c|c|c|}
\hline \multirow{3}{*}{ Legal organization } & \multicolumn{10}{|c|}{ Firm size by net sale level } \\
\hline & \multicolumn{2}{|l|}{ Large } & \multicolumn{2}{|l|}{ Medium } & \multicolumn{2}{|c|}{ Small } & \multicolumn{2}{|l|}{ Micro } & \multicolumn{2}{|l|}{ Total } \\
\hline & Obs. & $\%$ & Obs. & $\%$ & Obs. & $\%$ & Obs. & $\%$ & Obs. & $\%$ \\
\hline Open corporation & 149 & 5.51 & 27 & 1.30 & 18 & 0.47 & 8 & 0.13 & 202 & 1.37 \\
\hline Closed corporation & 1,391 & 51.57 & 618 & 29.48 & 401 & 10.32 & 195 & 3.23 & 2,604 & 17.69 \\
\hline Limited liability comp. & 937 & 34.75 & 1,044 & 49.83 & 1,546 & 39.82 & 1,008 & 16.67 & 4,535 & 30.81 \\
\hline $\begin{array}{l}\text { Individual limited liability } \\
\text { company }\end{array}$ & 60 & 2.22 & 67 & 3.21 & 156 & 4.02 & 119 & 1.97 & 402 & 2.73 \\
\hline Natural person & 61 & 2.28 & 262 & 12.49 & 1,636 & 42.15 & 4,475 & 74.03 & 6,434 & 43.72 \\
\hline Other structures & 99 & 3.67 & 77 & 3.69 & 125 & 3.22 & 240 & 3.97 & 541 & 3.68 \\
\hline Full sample & 2,697 & 18.32 & 2,096 & 14.24 & 3,881 & 26.37 & 6,045 & 41.07 & 14,719 & 100 \\
\hline
\end{tabular}

Note. Source: Own elaboration based on LBS data.

Agency costs $(\mathrm{AC})$ constitute the dependent variable in this study and were measured through operating expenses to sales ratio. The operating expenses included administration and sales expenses. This variable quantifies the costs associated with overinvestment and conflicts of interest between managers and owners (Ang et al., 2000; Fleming et al., 2005; Gogineni et al., 2016).

The return on assets (ROA) was used to separate the sample into firms with high growth opportunities (HGO) and low growth opportunities (LGO). Danbolt, Hirst, and Jones (2011) indicate that accounting indicators of actual returns such as ROA or ROE are positively and significantly correlated with measures of future firm growth (market to book equity, price to earnings ratio, or Tobin's Q). This justifies the use of this proxy as a measure of growth opportunities. Then, we calculated the ROA for each company and then determined the average

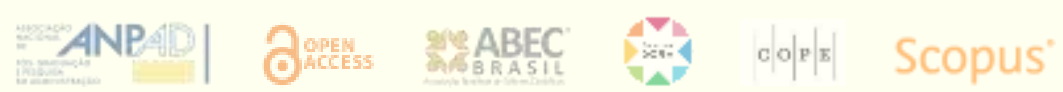


of this indicator for each economic sector and survey. Companies with HGOs would possess an above-average ROA, while those below the average would qualify as firms with LGOs. Finally, we define LGO as a dummy variable for firms with low growth opportunities.

Ownership structure is used to quantify the effect of ownership concentration and/or dilution on agency costs (Fleming et al., 2005; Singh \& Davidson, 2003). The ownership structure was measured through the dummy variables owner-manager (OS1), business associate manager (OS2), outsider-manager (OS3); and by managerial ownership (MOW). These measures have been suggested by previous studies (Ang et al., 2000; Fleming et al., 2005; Gogineni et al., 2016).

We measured managerial discretion through previous dismissal (MD1) and non-operating business related to the manager's past performance (MD2). These measures are related to the managers' discretionary behaviors in their previous job and also reflect the managers' ability to run companies and their intention to remain active in the managers' job market. Fama (1980) points out that managers establish their managerial compensation according to their marginal productivity and the reputation they develop over time. When managers deviate from their behavior, the labor market exercises a means of control that returns them to a state of interests aligned with the owners. Furthermore, the company's qualities and the effectiveness of the company's means of control can also align the managers' behavior to the owners' interests (Hayibor et al., 2011; Miller, 2011; Wade et al., 2006; 2008). However, Diamond and Verrecchia (1982) warn that managers take advantage of information asymmetry to hide their discretionary behavior in the randomness of the firm's performance and its growth opportunities. This assumes that the managerial discretion variables have two possible effects on agency costs: a direct channel that affects the agency costs of the current company and that would reflect the alignment effect of the manager's behavior described by their self-control and intention to remain active in the managers' job market (Fama, 1980; Miller, 2011); and another indirect channel that affects agency costs depending on the company's growth opportunities (Diamond \& Verrecchia, 1982).

Leverage (LEV) and monitoring by external investors (EM) are used as mitigation mechanisms of agency costs. According to previous studies, the firms' financing policy can mitigate the agency costs derived from the relationship between managers and owners (Ang et al., 2000; Fleming et al., 2005). However, agency costs also might increase when leverage is high because debt agency costs are more relevant (Jensen \& Meckling, 1976).

Table 2

\section{Categories and variable measurement}

\begin{tabular}{ll}
\hline Variable & Definition \\
\hline $\begin{array}{l}\text { Agency costs } \\
\text { AC Operating expenses to sales }\end{array}$ & Annual operating expenses to sales ratio \\
$\begin{array}{l}\text { Growth opportunities } \\
\text { ROA Return on assets }\end{array}$ & Net income to total assets ratio \\
Ownership structure & \\
OS $1 \quad$ Owner-manager & Dummy 1 if the manager is total owner and 0 otherwise
\end{tabular}

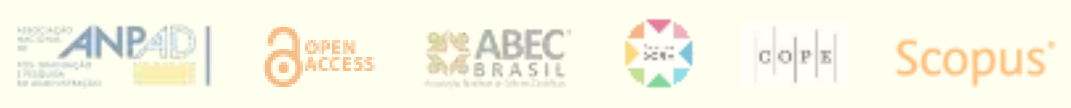




\section{Table 2 (continued)}

$\begin{array}{ll}\text { OS2 } & \text { Business associate manager } \\ \text { MOW } & \text { Managerial ownership } \\ \text { OS3 } & \text { Outsider-manager } \\ \text { Managerial discretion } \\ \text { MD1 } & \text { Previous dismissal } \\ \text { MD2 } & \text { Non-operating business } \\ & \\ \text { Financing and external monitoring } \\ \text { LEV } & \text { Debt to equity } \\ \text { EM } & \text { External monitoring } \\ \text { Other control variables } \\ \text { SIZE } & \text { Firm size } \\ \text { FQL } & \text { Altman Z-score }\end{array}$

Dummy 1 if the manager is an associate manager and 0 otherwise Equity share of business associate manager Dummy 1 if the manager is an outsider (non-owner) and 0 otherwise

Dummy 1 if the manager was dismissed from his previous managerial job Number of non-operating businesses previously managed by the manager

Total debt to equity ratio

Years extension of the relationship with external funders

Natural logarithm of total assets

Firm quality measured by Altman

Note. Source: Own elaboration.

Another control variable is size, measured by the natural logarithm of the firm's total assets (Cho, 1998; Daines, 2001; Offenberg, 2012; Yermack, 1996). Z-score was used as a measure of credit quality of the firms (Ross, 1977) and was measured through Altman Z-score for emerging markets, where the discrimination zones are safe zone (Z-score > 2.60), grey zone (Z-score between 2.60 and $1.1)$, and distress zone (Z-score $<1.1)$.

\section{Econometric methodology}

We estimated an instrumental variables (IV) regression to analyze the effect of managerial ownership structure, capital structure, and managerial discretion on agency costs. The empirical model is as follows:

$$
\begin{aligned}
A C_{i}= & { }_{0}+{ }_{1} O S_{i}+{ }_{2} M O W_{i}+{ }_{3} M O W_{i}^{2}+{ }_{4} E M_{i}+{ }_{5} L E V_{i}+{ }_{6} L E V_{i}^{2} \\
& +{ }_{7} M D_{i}+{ }_{8}\left(M D_{i} L G O\right)+{ }_{9} S_{Z Z E_{i}}+{ }_{10} F Q L_{i}+{ }_{11} L G O \\
& +{ }_{0} \text { DSector }_{i}+{ }_{1} \text { DYear }_{t}+{ }_{i}
\end{aligned}
$$

where $\mathrm{AC}_{i}$ indicates the agency costs. Furthermore, $\mathrm{OS}_{i}$ measures the ownership structure, defined through three dichotomous variables (Table 2). The variable $\mathrm{MOW}_{i}$ is the managerial ownership, while $\mathrm{MOW}_{i}^{2}$ measures quadratic managerial ownership in order to capture the possible nonlinear effect of managerial ownership on agency costs. In addition, $E M_{i}$ measures monitoring by external funders, $L E V_{i}$ measures firm capital structure using the debt-to-equity ratio, and $L E V_{i}^{2}$ captures the potential non-linear effect of debt on agency costs. The managerial discretion $M D_{i}$ was measured through the previous dismissal dummy variable and the number of previous nonoperational businesses, while $\left(M D_{i} \times L G O\right)$ corresponds to the interactive effect of managerial discretion in firms with low growth opportunities. Other control variables are $S_{2} Z E_{i}$, which measures firm size using the natural logarithm of total assets, and $F Q L_{i}$, which measures firm credit quality according to the Altman Z-Score. Finally, $\varepsilon_{i}$ represents a random disturbance. The estimated model included dummy variables to control the differences according to economic sectors and years. 
The use of an IV estimator is justified by the endogeneity between agency costs $\left(A C_{i}\right)$ with the firm's debt level $\left(L E V_{i}\right)$ and managerial ownership $\left(M O W_{i}\right)$. To apply the IV estimator, gross margin $\left(\mathrm{GM}_{i}\right)$, financial expenses coverage $\left(F E C_{i}\right)$, and manager experience $\left(\mathrm{MEX}_{i}\right)$ measured in years were used as instruments. These instruments were selected because they were not correlated with the error, but they were significantly correlated with the endogenous variable. We used the Hausman test to analyze the presence of endogeneity. In both estimation stages, we used dummy variables for the economic sector and years, and we also applied the robust variance estimator to correct heteroskedasticity patterns. We also applied a VIF test to verify multicollinearity and define the correct specification of the model (1).

\section{EMPIRICAL RESULTS}

\section{Descriptive analysis}

Table 3 shows the descriptive statistics. It is important to note that the surveys are not strictly comparable due to differences in sample size and the fact that companies do not necessarily repeat themselves from survey to survey. The descriptive results show that agency costs (AC), measured by the operating expenses to sales ratio, represent between $11.38 \%, 24.50 \%$, and $17.75 \%$ on average for each LBS, respectively. Regarding LBS1, an incremental trend of agency costs is shown. This may be due to the increased participation of large companies in LBS3.

From LBS1, we observe that the proportion of companies managed by their owners (OS1) decreases from $35.71 \%$ to $18.15 \%$, whereas those managed by outsider managers (OS3) increased from $27.23 \%$ to $45.19 \%$. This is due to the fact that in the sampling design of LBS1, small and micro companies had a greater participation, while large companies had a greater presence in LBS3. Compared to 2007, the proportion of companies managed by an owner/manager fell to $14.07 \%$ in 2009 and $17.56 \%$ in 2013. Accordingly, we observed a lower managerial ownership with figures ranging from $52.57 \%$ of the ownership in LBS1 to $35.45 \%$ in LBS3. This may be empirically related to the higher agency costs described previously.

Managerial discretion for 2007 indicates that 5.86\% of current company managers were dismissed from their previous managerial job (MD1) and 1.33 companies ceased to operate under their previous management (MD2). This first proportion fell to $2.89 \%$ and $1.51 \%$ for 2009 and 2013, respectively, while the second figure went from 0.39 to 0.25 .

Table 3

\section{Descriptive statistics}

\begin{tabular}{|c|c|c|c|c|c|c|}
\hline \multirow{2}{*}{ Variables } & \multirow{2}{*}{$\begin{array}{r}2007 \\
\text { Mean } \\
\end{array}$} & \multicolumn{2}{|c|}{2009} & \multicolumn{2}{|c|}{2013} & \multirow[b]{2}{*}{ S.D. } \\
\hline & & S.D. & Mean & S.D. & Mean & \\
\hline Agency costs & & & & & & \\
\hline Operating expenses to sales (\%) & 11.38 & 15.74 & 24.50 & 21.12 & 17.75 & 18.30 \\
\hline
\end{tabular}

Ownership structure

Continues

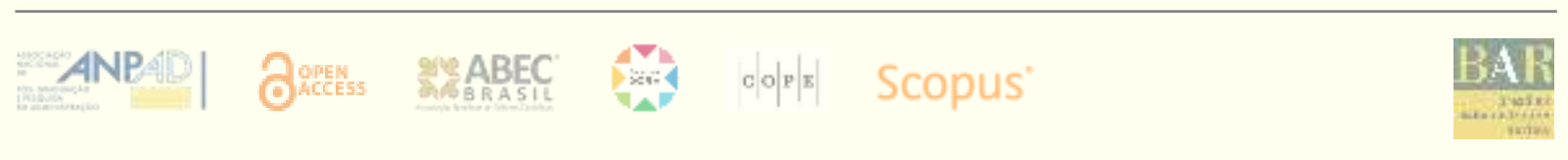




\section{Table 3 (continued)}

Owner/manager ${ }^{1}(\%)$

Business associate manager ${ }^{1}(\%)$

Managerial ownership (\%)

Outsider manager ${ }^{1}(\%)$

\begin{tabular}{rrrrrr}
35.71 & 49.60 & 21.64 & 41.21 & 18.15 & 38.54 \\
38.04 & 48.66 & 41.05 & 49.29 & 36.63 & 48.18 \\
52.57 & 28.29 & 50.79 & 27.94 & 35.45 & 41.42 \\
27.23 & 45.85 & 38.29 & 47.47 & 45.19 & 49.77 \\
& & & & & \\
5.86 & 22.49 & 2.89 & 12.64 & 1.51 & 12.21 \\
1.33 & 1.44 & 0.39 & 0.93 & 0.25 & 0.65 \\
& & & & & \\
1.45 & 2.14 & 1.52 & 2.13 & 2.09 & 2.56 \\
12.82 & 12.54 & 12.65 & 10.16 & 16.33 & 11.56 \\
& & & & & \\
20,443 & 338,402 & 150,163 & 816,120 & 168,401 & 683,462 \\
5.74 & 5.20 & 3.58 & 3.24 & 3.73 & 4.18 \\
\hline
\end{tabular}

Managerial discretion

Previous dismissal ${ }^{1}(\%)$

Non-operating business

Financing and external monitoring

Debt-to-equity

External monitoring

Other control variables

Firm size (total assets, million \$)

Altman Z-Score

Note. Source: Own elaboration based on LBS data.

${ }^{1}$ These measures correspond to dummy variables. The mean and standard deviation are expressed as a percentage to indicate the proportion of observations between 0 and 1 in each variable.

According to firms' leverage (LEV), Chilean companies mainly use debt as financing source. Moreover, firms maintain commercial relationships with external funders (EM), who play a role in monitoring the firms and their management. This relationship ranges from 12 to 16 years on average. Regarding firm credit quality (FQL), the Z-Score measure presents levels above 2.60. This reveals that, on average, Chilean firms have a low probability of bankruptcy.

Table 4

\section{Correlations between variables}

\begin{tabular}{|c|c|c|c|c|c|c|c|c|c|c|c|c|}
\hline$\gamma$ & $A C$ & ROA & OS1 & OS2 & MOW & OS3 & MD1 & MD2 & LEV & EM & SIZE & $\mathrm{FQL}$ \\
\hline$A C$ & 1.00 & & & & & & & & & & & \\
\hline ROA & $-0.04^{\star \star *}$ & 1.00 & & & & & & & & & & \\
\hline OS1 & $-0.11^{* \star *}$ & $0.14^{* * *}$ & 1.00 & & & & & & & & & \\
\hline OS2 & $0.05^{\star * *}$ & $-0.02^{* * *}$ & $-0.35^{\star * *}$ & 1.00 & & & & & & & & \\
\hline MOW & $-0.05^{\star * *}$ & $0.17^{\star \star \star}$ & $0.31^{* \star *}$ & $0.25^{\star \star \star}$ & 1.00 & & & & & & & \\
\hline OS3 & $0.06^{\star \star \star}$ & $-0.20^{\star \star \star}$ & $-0.28^{\star * *}$ & $-0.33^{* * *}$ & $-0.26^{\star \star \star}$ & 1.00 & & & & & & \\
\hline MD1 & $-0.03^{\star \star *}$ & $0.05^{\star \star *}$ & $0.12^{\star \star \star}$ & 0.01 & $0.11^{* * *}$ & $-0.13^{\star \star \star}$ & 1.00 & & & & & \\
\hline MD2 & $-0.06^{* * *}$ & $0.01^{*}$ & -0.01 & 0.02 & $-0.03^{*}$ & $-0.07^{\star}$ & $0.04^{\star * *}$ & 1.00 & & & & \\
\hline LEV & $-0.05^{\star \star *}$ & $0.06^{* * *}$ & $-0.14^{* * *}$ & $0.03^{* * *}$ & $-0.12^{* \star *}$ & $0.11^{* * *}$ & $-0.02^{* * *}$ & 0.02 & 1.00 & & & \\
\hline EM & $-0.01^{* * *}$ & $0.10^{* \star *}$ & $-0.06^{* * *}$ & $-0.05^{\star * *}$ & $-0.12^{* \star *}$ & $0.12^{* * *}$ & $-0.06^{* * *}$ & $-0.05^{\star \star \star}$ & $0.05^{\star \star \star}$ & 1.00 & & \\
\hline SIZE & $0.01^{\star \star \star}$ & $-0.16^{\star * *}$ & $-0.21^{\star * *}$ & -0.01 & $-0.21^{\star \star *}$ & $0.23^{\star \star *}$ & $-0.15^{\star \star *}$ & $-0.08^{\star \star *}$ & $0.13^{\star \star \star}$ & $0.15^{\star \star \star}$ & 1.00 & \\
\hline $\mathrm{FQL}$ & $-0.11^{\star \star *}$ & $0.10^{* *}$ & $0.18^{\star \star \star}$ & 0.00 & $0.08^{*}$ & $-0.10^{* *}$ & $0.06^{* * *}$ & $0.05^{\star \star *}$ & $-0.05^{\star * *}$ & $-0.13^{\text {***}}$ & $-0.19^{\star \star *}$ & 1.00 \\
\hline
\end{tabular}

Note. Source: Own elaboration based on LBS data.

${ }^{a}$ Superscripts ${ }^{* * *},{ }^{* *},{ }^{*}$ indicate statistical significance at 1,5 , and 10 percent, respectively.

Table 4 shows the correlations between the variables. The results indicate that the ownership concentration is negatively correlated with agency costs. The owner-manager dummy variable (OS1) and managerial ownership (MOW) are negatively and significantly correlated with agency costs, while the partner-manager (OS2) and manager-outsider (OS3) dummy variables show a positive correlation with these costs. Debt (LEV) and monitoring of external funders (EM) are negatively and significantly correlated with agency costs, which preliminarily suggests that financing policy plays an external supervisory role over the firm's corporate management. The measures of managerial discretion, previous dismissal (MD1) and non-operating businesses (MD2), are also negatively correlated with agency costs, which supposes a potential moderating

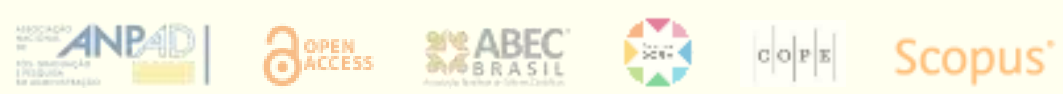


effect of conflicts of interest between owners and managers. Correlation analysis suggests that larger firms have higher agency costs, while the firm's credit quality (FQL) is negatively correlated with agency costs. Finally, the correlations between the independent variables are significant, but low. This suggests a low effect in terms of collinearity within the model (1).

\section{Univariate analysis by growth opportunities}

The results in Table 5 indicate the mean differences between HGO and LGO firms. Growth opportunities may be an implicit factor that determine agency costs and condition the effects of managerial discretion on them (Lang et al., 1995; D’Mello \& Miranda, 2010).

We calculated the ROA for each company and then determined the average of this indicator for each economic sector and survey. Companies with HGOs would have an above-average ROA, while those below average would qualify as firms with LGOs. Using this criterion, the original sample was divided into 6,917 companies with HGOs (2,984 companies from LBS1, 1,817 from LBS2, and 2,116 from LBS3) and 7,802 with LGOs (3,663 companies from LBS1, 2,065 from LBS2, and 2,074 from LBS3). According to the Chilean Ministry of Economy, for the sample design of each LBS, the participation of large companies increased from LBS1 to LBS3, which generated a lower proportion of companies classified as firms with low growth opportunities in LBS3.

Table 5

Wilcoxon test, mean differences by growth opportunities level

\begin{tabular}{|c|c|c|c|c|c|c|c|c|c|}
\hline \multirow{2}{*}{ Variables } & \multicolumn{3}{|l|}{2007} & \multicolumn{3}{|l|}{2009} & \multicolumn{3}{|l|}{2013} \\
\hline & High & Low & $z$-statistic & High & Low & $z$-statistic & High & Low & $z$-statistic \\
\hline \multicolumn{10}{|c|}{ Agency costs } \\
\hline $\mathrm{AC}$ & 11.55 & 12.91 & $(-4.26)^{\star \star \star}$ & 23.43 & 26.38 & $(-4.94)^{\star \star \star}$ & 15.24 & 19.47 & $(-9.80)^{\star \star *}$ \\
\hline \multicolumn{10}{|c|}{ Ownership structure } \\
\hline OS $1^{1}$ & 52.18 & 24.96 & $(24.43)^{* * *}$ & 40.16 & 17.04 & $(19.13)^{\star * \star}$ & 39.62 & 9.85 & $(21.58)^{\star * *}$ \\
\hline OS $2^{1}$ & 32.26 & 40.03 & $(-5.85)^{\star * *}$ & 38.57 & 41.11 & $(-2.06)^{* \star}$ & 31.26 & 34.86 & $(-3.80)^{* * *}$ \\
\hline MOW & 53.95 & 51.64 & $(2.31)^{\star \star}$ & 52.49 & 49.71 & $(2.52)^{\star *}$ & 50.50 & 25.36 & $(5.77)^{\star * *}$ \\
\hline OS3 $^{1}$ & 15.56 & 35.01 & $(-21.49)^{\star * \star}$ & 21.27 & 41.85 & $(-17.03)^{\star \star \star}$ & 29.12 & 55.29 & $(-22.89)^{\star \star \star}$ \\
\hline \multicolumn{10}{|c|}{ Managerial discretion } \\
\hline $\mathrm{MD}^{1}$ & 8.47 & 4.45 & $(6.35)^{\star * *}$ & 2.44 & 1.51 & $(2.91)^{\star * *}$ & 2.36 & 0.94 & $(4.48)^{\star * \star}$ \\
\hline MD2 & 1.32 & 1.35 & $(-0.31)$ & 0.37 & 0.41 & $(-1.02)$ & 0.28 & 0.21 & $(1.58)$ \\
\hline \multicolumn{10}{|c|}{ Financing and external monitoring } \\
\hline LEV & 1.17 & 1.63 & $(-8.88)^{\star \star \star}$ & 1.24 & 1.77 & $(-8.56)^{\star * *}$ & 1.81 & 2.70 & $(-9.93)^{* * *}$ \\
\hline EM & 10.96 & 14.84 & $(-13.79)^{\star \star \star}$ & 10.84 & 14.54 & $(-14.60)^{\star * \star}$ & 14.87 & 17.31 & $(-8.13)^{\star \star \star}$ \\
\hline \multicolumn{10}{|c|}{ Other control variables } \\
\hline SIZE & 9,113 & 28,303 & $(-3.33)^{\star * *}$ & 10,919 & 237,292 & $(-4.28)^{\star * *}$ & 21,692 & 301,479 & $(-5.77)^{\star \star *}$ \\
\hline $\mathrm{FQL}$ & 7.76 & 4.10 & $(31.18)^{\star * \star}$ & 5.26 & 2.32 & $(35.84)^{\star * *}$ & 5.72 & 2.49 & $(31.07)^{\star * \star}$ \\
\hline
\end{tabular}

Note. Source: Own elaboration based on LBS data.

${ }_{1}^{1}$ These measures correspond to dummy variables. The mean and standard deviation are expressed as a percentage to indicate the proportion of observations between 0 and 1 in each variable.

a Superscripts ${ }^{* * *},{ }^{* *},{ }^{*}$ indicate statistical significance at 1,5 , and 10 percent, respectively.

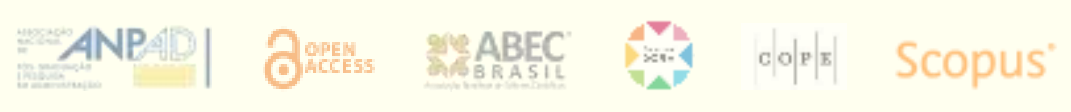


Firms with HGOs have lower agency costs compared to firms with LGOs. Operational costs to sales ratios show a significant difference at $1 \%$ between these firms. These results are consistent with Jensen (1986), who indicates that firms with LGOs have a greater incentive to overinvest and have higher conflict of interests between owners and managers. Regarding ownership structure, companies with HGOs are mainly managed by their owners, while firms with LGOs are mainly managed by a business associate manager or an outsider. Accordingly, in firms with HGOs, managerial ownership is significantly higher. These results support the findings of Jensen (1986) and Fleming, Heaney, and McCosker (2005) that companies with LGOs have more diluted ownership structure and higher agency costs.

Financing policy also has significant differences between firms with HGOs and LGOs. Firms with LGOs have higher leverage (LEV) and a more extensive relationship with external investors (EM). In general, these companies are monitored by financial institutions and external creditors because their set of investment projects is limited. These means of control may be marginally less effective due to high firm indebtedness.

Managerial discretion variables indicate that there is a higher proportion of managers who were dismissed from their previous managerial job in firms with HGOs. This result leaves out the possibility that such firms hire these managers under expensive monitoring to control their discretionary behaviors. The variable that represents the number of non-operational businesses does not differ significantly between firms with HGOs and LGOs. According to the Z-Score measure, firms with HGOs are characterized by a higher credit quality. Finally, companies with LGOs are larger.

\section{Effects of managerial ownership, capital structure, and managerial discretion on agency costs}

Table 6 shows the results of the model (1). This model was estimated using the IV method due to the presence of endogeneity in leverage (LEV) and managerial ownership (MOW). The Hausman test was significant at $1 \%$ in all cases, confirming the existence of endogeneity. To correct this specification problem, endogenous variables were instrumentalized through gross margin (GM), financial expense coverage (FEC), and manager's experience (MEX). The Sargan test supported that the model is overidentified, and therefore the instruments are exogenous and valid. According to the White test, the model presented heteroskedasticity problems, which were corrected with the use of robust variance estimators. Finally, the collinearity analysis revealed that there were no relevant correlations between the regressors, as none of them had a VIF greater than 10. The information in Table 4 even confirmed that although there were significant correlations between the regressors, these were low and supported the results of VIF.

According to Table 6, firm size positively and significantly affects agency costs. This result demonstrates the difficulty of managing companies with greater structural complexity and the weakening of internal monitoring mechanisms in larger firms (Cho, 1998; Daines, 2001; Offenberg, 2012; Yermack, 1996). The results also show that firms with better quality have lower agency costs (Ross, 1977), and firms with LGO have higher agency costs.

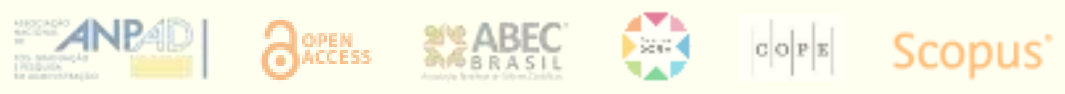


Ownership structure also had significant effects on agency costs. The owner-manager dummy variable (OS1) had a negative effect on agency costs, while the OS2 and OS2 dummy variables had a positive and significant impact on them. According to previous studies, these results reveal that ownership concentration reduces agency costs because it strengthens internal monitoring and encourages managers to self-impose behavioral constraints to align their interests with those of the owners (Ang et al., 2000; Fleming et al., 2005; Gogineni et al., 2016; Singh \& Davidson, 2003). Even the managerial ownership variable (MOW) had a significant negative effect on agency costs, which is in line with the results already described. However, the impact of managerial ownership was non-linear and U-shaped, which validated hypothesis H1. The managerial ownership that minimizes agency costs in Chilean firms is $97.14 \%$ (average of critical values). These results demonstrate that the effect of managerial entrenchment associated with ownership concentration does not exist in Chilean companies. Firms with HGOs have an average managerial ownership of $52.31 \%$, while firms with LGO have an average managerial ownership of $42.24 \%$. This result indicates that in these firms, the deterrent effect of managerial ownership concentration on agency costs is large and does not allow managers to become entrenched in corporate management.

Table 6

IV regression for agency costs

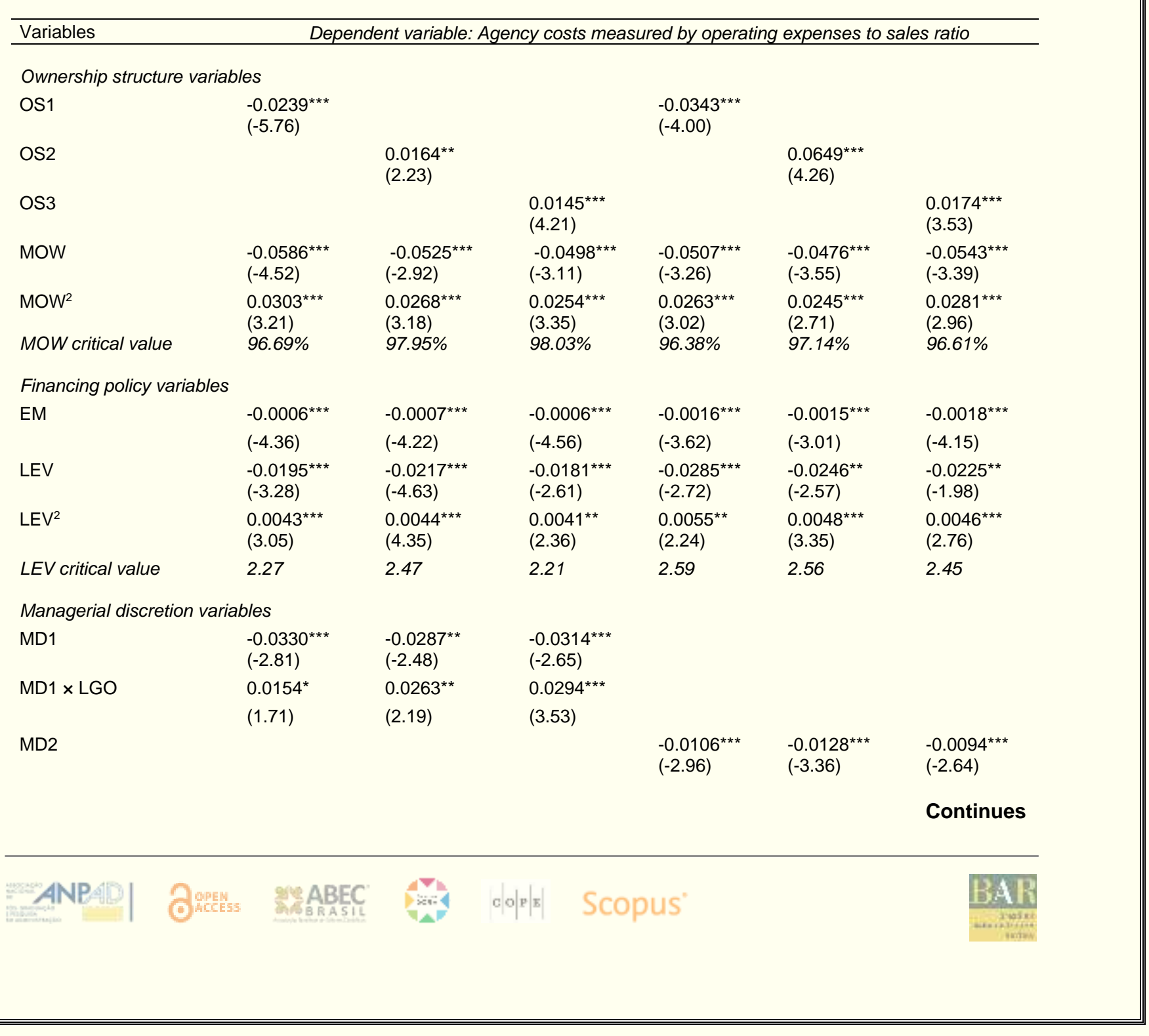




\section{Table (continued)}

\begin{tabular}{|c|c|c|c|c|c|c|}
\hline \multicolumn{4}{|l|}{ MD2 × LGO } & $\begin{array}{l}0.0067^{* *} \\
(2.53)\end{array}$ & $\begin{array}{l}0.0109^{\star * *} \\
(2.66)\end{array}$ & $\begin{array}{l}0.0099^{* *} \\
(2.42)\end{array}$ \\
\hline \multicolumn{7}{|c|}{ Other control variables } \\
\hline SIZE & $\begin{array}{l}0.0090^{* * *} \\
(11.97)\end{array}$ & $\begin{array}{l}0.0097^{* * *} \\
(9.27)\end{array}$ & $\begin{array}{l}0.0087^{* * *} \\
(11.36)\end{array}$ & $\begin{array}{l}0.0173^{* \star *} \\
(7.84)\end{array}$ & $\begin{array}{l}0.0233^{\star * *} \\
(9.26)\end{array}$ & $\begin{array}{l}0.0139^{\star * \star} \\
(6.70)\end{array}$ \\
\hline $\begin{array}{l}\text { FQL } \\
\text { LGO }\end{array}$ & $\begin{array}{l}-0.0098^{* \star *} \\
(-25.21) \\
0.0594^{\star * *} \\
(6.64)\end{array}$ & $\begin{array}{l}-0.0102^{* * *} \\
(-19.49) \\
0.0650^{\star * \star} \\
(5.28)\end{array}$ & $\begin{array}{l}-0.0097^{\star * *} \\
(-25.05) \\
0.0628^{\star \star *} \\
(7.04)\end{array}$ & $\begin{array}{l}-0.0146^{\star * *} \\
(-14.67) \\
0.0602^{\star * \star} \\
(3.78)\end{array}$ & $\begin{array}{l}-0.0154^{* \star *} \\
(-13.19) \\
0.0577^{\star * \star} \\
(3.15)\end{array}$ & $\begin{array}{l}-0.0144^{* * *} \\
(-14.41) \\
0.0648^{\star \star *} \\
(2.86)\end{array}$ \\
\hline Const. & $\begin{array}{l}0.3882^{* * *} \\
(36.71)\end{array}$ & $\begin{array}{l}0.4393^{\star * *} \\
(26.57)\end{array}$ & $\begin{array}{l}0.3684^{* * *} \\
(39.12)\end{array}$ & $\begin{array}{l}0.5735^{\star \star \star} \\
(19.28)\end{array}$ & $\begin{array}{l}0.5624^{\star \star *} \\
(15.07)\end{array}$ & $\begin{array}{l}0.5137^{\star * *} \\
(20.12)\end{array}$ \\
\hline $\begin{array}{l}\text { Sample } \\
\text { Global F-test } \\
\text { Adj. R-Square } \\
\text { Sargan test } \\
\text { VIF mean }{ }^{1} \\
\text { VIF higher } \\
\text { White test } \\
\text { Hausman test } \\
\text { Sector dummy } \\
\text { Time dummy } \\
\text { Robust variance }\end{array}$ & $\begin{array}{l}14,719 \\
(48.63)^{\star \star *} \\
0.36 \\
(21.48) \\
(3.57) \\
(5.25) \\
(65.94)^{\star \star \star} \\
(17.21)^{\star \star *} \\
\text { Yes } \\
\text { Yes } \\
\text { Yes }\end{array}$ & $\begin{array}{l}14,719 \\
(41.29)^{\star \star \star} \\
0.39 \\
(25.16) \\
(2.57) \\
(4.93) \\
(72.07)^{\star \star \star} \\
(23.91)^{\star \star \star} \\
\text { Yes } \\
\text { Yes } \\
\text { Yes }\end{array}$ & $\begin{array}{l}14,719 \\
(49.06)^{\star \star \star} \\
0.41 \\
(23.08) \\
(3.38) \\
(5.10) \\
(60.86)^{\star \star \star} \\
(19.42)^{\star * \star} \\
\text { Yes } \\
\text { Yes } \\
\text { Yes }\end{array}$ & $\begin{array}{l}14,719 \\
(35.04)^{\star * *} \\
0.40 \\
(20.64) \\
(4.01) \\
(5.55) \\
(88.12)^{\star * *} \\
(20.36)^{* * *} \\
\text { Yes } \\
\text { Yes } \\
\text { Yes }\end{array}$ & $\begin{array}{l}14,719 \\
(39.29)^{\star * \star} \\
0.32 \\
(23.95) \\
(4.26) \\
(5.19) \\
(76.31)^{* * \star} \\
(15.97)^{* * *} \\
\text { Yes } \\
\text { Yes } \\
\text { Yes }\end{array}$ & $\begin{array}{l}14,719 \\
(37.18)^{\star \star *} \\
0.38 \\
(26.83) \\
(2.94) \\
(4.81) \\
(81.25)^{\star * \star} \\
(19.03)^{\star * *} \\
\text { Yes } \\
\text { Yes } \\
\text { Yes }\end{array}$ \\
\hline
\end{tabular}

Note. Source: Own elaboration based on LBS data.

${ }^{1}$ VIF mean is the average variance inflation factor of all the coefficients of the model (1).

${ }^{2}$ VIF higher represents the higher VIF associated to the coefficients of the model (1).

a Superscripts ${ }^{* * *},{ }^{* *},{ }^{*}$ indicate statistical significance at 1,5 , and 10 percent, respectively.

Monitoring by external funders negatively and significantly affects agency costs. A more extensive relationship with external funders reduces agency costs and disciplines managers. This extensive relationship limits discretionary managerial decisions on the investment policy of Chilean companies, particularly asset substitution and overinvestment.

Leverage negatively and significantly affects agency costs. This result corroborates that debt acts as a means of external control that mitigates agency problems between owners and managers (Fleming et al., 2005; Gogineni et al., 2016). Furthermore, the impact of leverage on agency costs is non-linear and U-shaped. This result supports hypothesis H2. This type of non-linear relationship suggests that the initial negative impact on agency costs is reversed when indebtedness is high. The leverage level that minimizes agency costs is given by a debt-to-equity ratio of 2.42 (70.79\% debt to assets ratio). Then, from this threshold value, the total agency costs increase because debt agency costs between the firm and creditors are more relevant. Firms with HGOs have an average debt-to-equity ratio of 1.41, while for firms with LGOs it is 2.03 . This suggests that the deterrent effect of leverage on total agency costs is more extensive for firms with HGOs and less relevant for companies with LGOs.

Managerial discretion has significant effects on agency costs. The variables of managerial discretion establish a trade-off between the manager's past discretionary behaviors and the current behaviors aligned with managerial self-control, and the supervision exercised by the corporate governance mechanisms of the companies and the managers' labor market. Table 6 indicates that the dummy variable of previous dismissal (MD1) and the number of previous non-operating businesses (MD2) had a significant and negative impact on agency costs. This result corroborates 
hypothesis H3. These findings indicate that managers align their behaviors and interests with their current companies, promoting lower agency costs. This result agrees with Stanwick and Stanwick (2003), Wade, Porac, Pollock and Graffin (2006), and Hayibor, Agle, Sears, Sonnenfeld, and Ward (2011). However, the variable $(\mathrm{MD} \times \mathrm{LGO})$ had a positive and significant impact on agency costs, which validates hypothesis $\mathrm{H} 4$. This result shows that when firms have low growth opportunities, managers take advantage of information asymmetries to act with discretion. This behavior would be hidden in the randomness of the firm's output and by less effective means of control (Diamond \& Verrecchia, 1982; Miller, 2011). Therefore, managerial discretion increases agency costs.

\section{DISCUSSION}

The results of this research have important empirical implications for the academic development of corporate finance and constitute a practical guide for the implementation of improvements in corporate governance of firms in the region and other emerging countries.

Empirically, our work provides evidence that describes the relationship of managerial ownership, capital structure, and managerial discretion on agency costs. Several previous studies, even the most traditional and seminal works, have supported the control effect of managerial ownership on agency costs (Ang et al., 2000; Fleming et al., 2005; Florackis, 2008; Gogineni et al., 2016; Jensen \& Meckling, 1976; Katti \& Raithatha, 2018; Ruiqi et al., 2017; Ross, 1977). Our study also supports this conclusion. However, what is interesting about our research is that the detected non-linear relationship (U-shaped) between managerial ownership and agency costs suggests that the control effect of managerial ownership fades marginally, reaching its maximum impact on the agency costs when ownership is fully concentrated. In the practice of markets and firms, this finding advises them that higher managerial ownership strengthens corporate control and does not favor the entrenchment of management, as other studies warn (Berger et al., 1997; De Angelo \& De Angelo, 1985). In academic terms, the non-linear relationship between managerial ownership and agency costs offered by this research provides a clear answer to the empirical debate between two opposing views: the control hypothesis and the managerial entrenchment hypothesis. The managerial ownership level generates a trade-off between both points of view, which ultimately suggests an optimal ownership structure that minimizes agency costs.

The financing policy can also be used as a means of control. The empirical discussion supports that debt reduces agency costs because companies and managers are more exposed to external supervision from funders (Ang et al., 2000; Fleming et al., 2005; Rakesh \& Lakshmi, 2013; Zhang $\& \mathrm{Li}, 2008)$. Our research also suggests that companies and managers issue debt to reduce agency costs, albeit with caution. The non-linear relationship found in this research and that describes the impact of leverage on agency costs suggests that the external control exercised by debt is gradually reduced. This empirical contribution reveals that marginal debt could increase agency costs due to the predominance of bankruptcy costs, as described in other studies (Pandey \& Sahu, 2019; Zhang \& Li, 2008). The effectiveness of debt to control agency costs depends on the level of leverage of the firm. Companies should adapt their financing policy not only to the qualities of their businesses but also to the magnitude of agency costs they have to take advantage of their potential to control these costs.

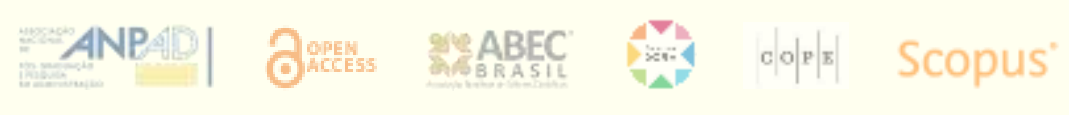


Managerial discretion is another empirical contribution of this research, both for Chile and for developed and emerging markets. Several studies have shown that the managers' discretionary behavior depends on the effectiveness of the company's means of control (Hayibor et al., 2011; Katti \& Raithatha, 2018; Wade et al., 2006; 2008). Our findings have important practical implications in this matter, as they reveal that discretionary administrators generate higher agency costs when firms have lower growth opportunities. Given this situation, companies could use their corporate performance and future growth measures as control parameters over managers' discretionary conduct, thus limiting the generation of agency costs and losses in operational efficiency.

Finally, it is important to mention that this research has limitations in the data structure. The data throughout the three surveys do not allow identifying the companies and using them through a panel data structure. This disadvantage prevents the visualization of idiosyncratic and temporary patterns that structurally affect the agency costs of companies.

\section{CONCLUSIONS}

The agency theory has recently gained interest due to its relevance to firms' corporate decisions. Vast theoretical and empirical literature has studied agency costs, highlighting the role of ownership structure, capital structure, firm size, and firm growth opportunities as determining factors. However, in Chile, the evidence is scarce and studies have mainly addressed large companies listed on stock exchange. In addition, no study has covered how managerial discretion affects agency costs until now.

Our research analyzes the effects of managerial ownership, capital structure, and managerial discretion on agency costs. Our research meets three objectives that support its empirical contributions. First, ownership concentration is an internal mechanism capable of mitigating agency costs in Chilean companies. Our results show that higher managerial ownership reduces agency costs. However, its effect is non-linear and U-shaped. The described non-linear effect suggests that when managerial ownership is less than $97.29 \%$, the control effect of managerial ownership predominates over agency costs. For higher levels, this effect is reversed. Considering this critical value, the managerial entrenchment effect is ruled out and total ownership concentration is an internal control means that minimizes agency costs in Chilean companies.

Second, the capital structure is a means of external control over agency costs. Our evidence supports that leverage significantly reduces agency costs, although its effect is non-linear. The U. shape of this relationship shows that the control effect on agency costs vanishes when it reaches the critical level of leverage (2.42 debt-to-equity or $70.79 \%$ debt-to-assets). As leverage exceeds this threshold, agency costs increase due to the predominance of debt agency costs (mainly bankruptcy costs). The initial deterrent effect of leverage on total agency costs is broader for firms with HGOs and less relevant for companies with LGOs. Our results allow us to argue that Chilean firms have a capital structure that minimizes agency costs, but their effectiveness in controlling such costs depends on the debt level. 
Third, managerial discretion reduced agency costs. Our results suggest that managers align their behaviors and interests with their current companies, promoting lower agency costs. However, the effects of managerial discretion on agency costs depend on growth opportunities. When firms have low growth opportunities, managerial discretion increases agency costs. This result implies that managers take advantage of information asymmetries to act at their discretion and favor their own interests. Low growth opportunities imply less effective means of internal control and incentive managers to hide their performance in the randomness of the firm's output.

\section{Funding}

Universidad de Concepción. Proyecto VRID Iniciación 215.420.003-1.0IN.

\section{REFERENCES}

Aktas, N., Andreou, P., Karasamani, I., \& Philip, D. (2019). CEO duality, agency costs, and internal capital allocation efficiency. British Journal of Management, 30(2), 473-493. https://doi.org/10.1111/14678551.12277

Alderson, M., \& Betker, B. (2003). Managerial discretion costs and the acquisition of capital: Evidence from forced warrant exercise. Financial Management, 32(1), 109-126. Retrieved from https://www.jstor.org/stable/3666206

Ang, J., Cole, R., \& Lin, J. (2000). Agency costs and ownership structure. The Journal of Finance, 55(1), 81-106. https://doi.org/10.1111/0022-1082.00201

Balkin, D. (2008). Explaining high US CEO pay in a global context. An institutional perspective (pp. 192-205). In L. R. Gomez-Mejia, \& S. Werner (Eds.), Global compensation: Foundations and Perspectives. Routledge: Abingdon.

Berger, P., Ofek, E., \& Yermack, D. (1997). Managerial entrenchment and capital structure decisions. The Journal of Finance, 52(4), 1411-1438. https://doi.org/10.1111/j.1540-6261.1997.tb01115.x

Berle, A., \& Means, G. (1932). The modern corporation and private property. New York: Macmillan.

Booth, L., Aivazian, V., Demirgüc-Kunt, A., \& Maksimovic, V. (2001). Capital structures in developing countries. The Journal of Finance, 56(1), 87-130. https://doi.org/10.1111/0022-1082.00320

Borlea, S., Achim, M. \& Mare, C. (2017). Board characteristics and firm performances in emerging economies. Lessons from Romania. Economic Research-Ekonomska Istraživanja, 30(1), 55-75. https://doi.org/10.1080/1331677X.2017.1291359

Cho, M. (1998). Ownership structure, investment, and the corporate value: An empirical analysis. Journal of Financial Economics, 47(1), 103-121. https://doi.org/10.1016/S0304-405X(97)00039-1

Daines, R. (2001). Does Delaware law improve firm Value? Journal of Financial Economics, 62(3), 525-558. https://doi.org/10.1016/S0304-405X(01)00086-1

Danbolt, J., Hirst, I., \& Jones, E. (2011). The growth companies puzzle: Can growth opportunities measures predict firm growth? The European Journal of Finance, 17(1), 1-25. https://doi.org/10.1080/13518470903448432

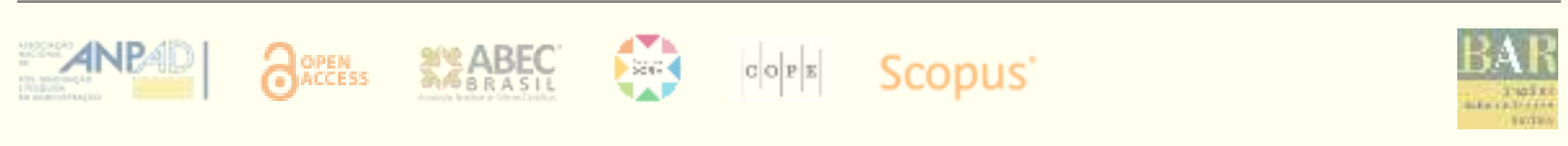


De Andrés, P., San Martín, P., \& Saona, P. (2004). Decisiones financieras en la empresa chilena: Una mirada a través de las oportunidades de crecimiento. Revista Abante, 7(1), 3-34. Retrieved from https://www.researchgate.net/publication/5224161_DECISIONES_FINANCIERAS_EN_LA_EMPRESA _CHILENA_UNA_MIRADA_A_TRAVES_DE_LAS_OPORTUNIDADES_DE_CRECIMIENTO

De Angelo, H., \& De Angelo, L. (1985). Managerial ownership of voting rights: A study of public corporations with dual classes of common stock. Journal of Financial Economics, 14(1), 33-69. https://doi.org/10.1016/0304$405 X(85) 90043-1$

De Gregorio, J., García, N. \& Jara-Bertin, M. (2017). The Boom of corporate debt in latin America: Carry trade or investment? http://dx.doi.org/10.2139/ssrn.3034290

D'Mello, R., \& Miranda, M. (2010). Long-term debt and overinvestment agency problem. Journal of Banking and Finance, 34(2), 324-335. https://doi.org/10.1016/j.jbankfin.2009.07.021

Denis, D., \& McConnell, J. (2003). International corporate governance. Journal of Financial and Quantitative Analysis, 38(1), 1-36. https://doi.org/10.2307/4126762

Demsetz, H. (1983). The structure of ownership and the theory of the firm. Journal of Law and Economics, 26(2), 375 393. Retrieved from https://www.jstor.org/stable/725108

Demsetz, H., \& Villalonga, B. (2001). Ownership structure and corporate performance. Journal of Corporate Finance, 7(3), 209-233. https://doi.org/10.1016/S0929-1199(01)00020-7

Diamond, D., \& Verrecchia, R. (1982). Optimal managerial contracts and equilibrium securities prices. The Journal of Finance, 37(2), 275-287. https://doi.org/10.1111/j.1540-6261.1982.tb03550.x

Fama, E. (1980). Agency problems and the Theory of the firms. The Journal of Political Economy, 88(2), 288-307. https://doi.org/10.1086/260866

Fleming, G., Heaney, R., \& McCosker, R. (2005). Agency costs and ownership structure in Australia. Pacific-Basic Finance Journal, 13(1), 29-52. https://doi.org/10.1016/j.pacfin.2004.04.001

Florackis, C. (2008). Agency costs and corporate governance mechanisms: Evidence for UK firms. International Journal of Managerial Finance, 4(1), 37-59. https://doi.org/10.1108/17439130810837375

Florackis, C., \& Ozkan, A. (2009). The impact of managerial entrenchment on agency costs: An empirical investigation using UK panel data. European Financial Management, 15(3), 497-528. https://doi.org/10.1111/j.1468-036X.2007.00418.x

Gogineni, S., Linn, S., \& Yadav, P. (2016). Ownership structure, management control and agency costs. University of Wyoming, working paper. $\quad$ Retrieved from https://pdfs.semanticscholar.org/284b/6d72e5bf468dd2297558098ad2227eef3654.pdf

Hai, J., Min, H. \& Barth, J. (2018). On foreign shareholdings and agency costs: New evidence from China. Emerging Markets Finance and Trade, 54(12), 2815-2833. https://doi.org/10.1080/1540496X.2017.1412949

Harvey, C., Lins, K., \& Roper, A. (2001). The effect of capital structure when expected agency costs are extreme. Journal of Financial Economics, 74(1), 3-30. https://doi.org/10.1016/j.jfineco.2003.07.003

Hastori, U., Siregar, H., Sembel, R., \& Maulana, A. (2015). Agency costs, corporate governance and ownership concentration: The case of agro-industrial companies in Indonesia. Asian Social Science, 11(18), 311-319. http://dx.doi.org/10.5539/ass.v11n18p311

Hayibor, S., Agle, B., Sears, G., Sonnenfeld, J., \& Ward, A. (2011). Value congruence and charismatic leadership in CEO - Top manager relationships: An empirical investigation. Journal of Business Ethics, 102(2), 237-254. https://doi.org/10.1007/s10551-011-0808-y 
Iatridis, G. (2012). Audit quality in common-law and code-law emerging markets: Evidence on earnings conservatism, agency costs and cost of equity. Emerging Markets Review, 13(2), 101-117. https://doi.org/10.1016/j.ememar.2012.01.001

Jensen, M.C. (1986). Agency costs of free cash flow, corporate finance, and takeovers. American Economic Review, 76(2), 323-329. Retrieved from https://www.jstor.org/stable/1818789

Jensen, M., \& Meckling, W. (1976). Theory of the firm: Managerial behavior, agency costs and capital structure. Journal of Financial Economics, 3(4), 305-360. https://doi.org/10.1016/0304-405X(76)90026-X

Katti, S. \& Raithatha, M. (2018). Governance practices and agency cost in emerging market: Evidence from India. Managerial and Decision Economics, 39(6), 712- 732. https://doi.org/10.1002/mde.2940

Khan, A., Mihret, D., \& Muttakin, M. (2016). Corporate political connections, agency costs and audit quality. International Journal of Accounting E Information Management, 24(4), 357-374. https://doi.org/10.1108/IJAIM05-2016-0061

La Porta, R., Lopez de Silanes, F., \& Shleifer, A. (1999). Corporate ownership around the world. The Journal of Finance, 54(2), 471-517. https://doi.org/10.1111/0022-1082.00115

Lang, L., Poulsen, A., \& Stulz, R. (1995). Asset sales, firm performance, and the agency costs of managerial discretion. Journal of Financial Economics, 37(1), 3-37. https://doi.org/10.1016/0304-405X(94)00791-X

Lefort, F., \& Walker, E. (2007). Do markets penalize agency conflicts between controlling and minority shareholders? Evidence from Chile. The Developing Economies, 45(3), 283-314. https://doi.org/10.1111/j.17461049.2007.00044.x

Li, H., \& Cui, L. (2003). Empirical study of capital structure on agency costs in Chinese listed firms. Nature and Science, 1(1), 12-20. Retrieved from http://www.sciencepub.net/nature/0101/02-li.pdf

Maquieira, C., \& Danús, M. (1998). Costos de agencia y costos de transacción como determinantes de la tasa de pago de dividendos en Chile. Estudios de Administración, 5(2), 49-81. Retrieved from http://repositorio.uchile.cl/handle/2250/127112

Maquieira, C., \& Moncayo, I. (2004). Costos de agencia y costos de transacción como determinantes de la tasa de pago de dividendos en Chile: Extensión. Estudios de Administración, 11(2), 1-26. Retrieved from https://estudiosdeadministracion.uchile.cl/index.php/EDA/article/view/56799

Miller, S. (2011). Managerial discretion and corporate governance in publicly traded firms: Evidence from the property-liability insurance industry. Journal of Risk and Insurance, 78(3), 731-760. https://doi.org/10.1111/j.1539-6975.2011.01415.x

Morck, R., Shleifer, A., \& Vishny, R. (1989). Alternative mechanisms for corporate control. American Economic Review, 79(4), 842-852. Retrieved from http://www.jstor.org/stable/1827936

Morellec, E. (2004). Can managerial discretion explain observed leverage ratios? The Review of Financial Studies, 17(1), 257-294. https://doi.org/10.1093/rfs/hhg036

Offenberg, D. (2012). Agency costs and the size discount: Evidence from acquisitions. Journal of Economics, Finance and Administrative $\quad$ Science, 15(29), 73-93. Retrieved from http://jefas.esan.edu.pe/index.php/jefas/article/view/249

Pandey K. \& Sahu, T. (2019). Debt financing, agency cost and firm performance: Evidence from India. Vision, 23(3), 267-274. https://doi.org/10.1177/0972262919859203

Paredes, M., \& Flor, R. (1993). Estructura de propiedad: ¿Maximizan ganancias las empresas en Chile? El Trimestre Económico, 60(4), 885-908.

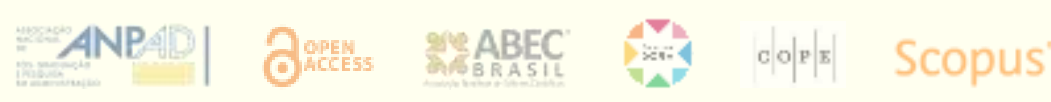


Park, C. (2000). Monitoring and structure of debt contracts. The Journal of Finance, 55(5), 2157-2195. https://doi.org/10.1111/0022-1082.00283

Rakesh, H., \& Lakshmi, P. (2013). Capital structure on agency costs: Evidence from Indian public companies. Journal of Business and Management, 15(1), 50-53. https://doi.org/10.9790/487X-1515053

Rashid, H., Khidmat, W., Al Hares, O., Muhammad, N. \& Saleem, K. (2020). Corporate governance quality, ownership structure, agency costs and firm performance. Evidence from an emerging economy, Journal of Risk and Financial Management, 13(7), 1-33. https://doi.org/10.3390/jrfm13070154

Ross, S. (1977). The determination of financial structure: The incentive-signalling approach. The Bell Journal of Economics, 8(1), 23-40. https://doi.org/10.2307/3003485

Ruiqi, W., Wang, F., Xu, L. \& Yuan, C. (2017). R\&D expenditures, ultimate ownership and future performance: Evidence from China. Journal of Business Research, 71, 45-74. https://doi.org/10.1016/j.jbusres.2016.10.018

Sass, T., \& Gisser, S. (1989). Agency cost, firm size, and exclusive dealing. The Journal of Law and Economics, 32(2), 381-400. Retrieved from https://www.jstor.org/stable/725428

Schäuble, J. (2019). The impact of external and internal corporate governance mechanisms on agency costs. Corporate Governance, 19(1), 1-22. https://doi.org/10.1108/CG-02-2018-0053

Shleifer, A., \& Vishny, R. (1997). A survey of corporate governance. The Journal of Finance, 52(2), 737-783. https://doi.org/10.1111/j.1540-6261.1997.tb04820.x

Singh, M., \& Davidson, W. (2003). Agency costs, ownership structure and corporate governance mechanisms. Journal of Banking and Finance, 27(5), 793-816. https://doi.org/10.1016/S0378-4266(01)00260-6

Smith, C., \& Warner, J. (1979). On financial contracting: An analysis of bond covenants. Journal of Financial Economics, 7(2), 117-161. https://doi.org/10.1016/0304-405X(79)90011-4

Stanwick, P., \& Stanwick, S. (2003). CEO and ethical reputation: Visionary or mercenary? Management Decision, 41(10), 1050-1057. https://doi.org/10.1108/00251740310509571

Stulz, R. (1990). Managerial discretion and optimal financing policies. Journal of Financial Economics, 26(1), 3-27. https://doi.org/10.1016/0304-405X(90)90011-N

Wade, J., Porac, J., Pollock, T., \& Graffin, S. (2006). The burden of celebrity: the impact of CEO certification contests on CEO pay and performance. Academy of Management Journal, 49(4), 643-660. https://doi.org/10.5465/amj.2006.22083021

Wade, J., Porac, J., Pollock, T., \& Graffin, S. (2008). Star CEOs: Benefit or burden? Organizational Dynamics, 37(2), 203-210. https://doi.org/10.1016/j.orgdyn.2008.02.007

Yermack, D. (1996). Higher market valuation of companies with a small board of directors. Journal of Financial Economics, 40(2), 185-211. https://doi.org/10.1016/0304-405X(95)00844-5

Zhang, H., \& Li, S. (2008, July). The impact of capital structure on agency costs: Evidence from UK public companies (pp. 1-18). In L. Cheng-Fee (Ed.), Proceedings of the Annual Conference on Pacific Basin Finance, Economics, Accounting and Management, Brisbane, Australia, 16.

Zhang, X., Tang, G. \& Lin, Z. (2016). Managerial power, agency cost and executive compensation-An empirical study from China. Chinese Management Studies, 10(1), 119-137. https://doi.org/10.1108/CMS-11-2015-0262 


\section{Authors' contributions}

$1^{\text {st }}$ author: conceptualization (lead), formal analysis (lead), investigation (lead), methodology (lead), project administration (lead), resources (lead), software (lead), writing-original draft (lead), writing-review \& editing (lead). $2^{\text {nd }}$ author: conceptualization (supporting), formal analysis (supporting), investigation (equal), methodology (supporting),software (supporting), writing-original draft (equal), writing-review \& editing (equal).

$3^{\text {rd }}$ author: conceptualization (supporting), formal analysis (supporting), investigation (supporting), software (supporting), writing-original draft (equal), writing-review \& editing (equal).

$4^{\text {th }}$ author: conceptualization (supporting), formal analysis (supporting), investigation (supporting), writing-original draft (supporting), writing-review \& editing (supporting).

\section{Authors}

Jorge Andrés Muñoz Mendoza*

Universidad de Concepcion, Departamento de Gestión Empresarial Juan Antonio Coloma 0201, 4440000, Los Ángeles, Bío-Bio, Chile jormunozm@udec.cl

https://orcid.org/0000-0002-6775-5307

\section{Sandra María Sepúlveda Yelpo}

Universidad de Concepción, Departamento de Gestión Empresarial Juan Antonio Coloma 0201, 4440000, Los Ángeles, Bío-Bio, Chile ssepulveday@udec.cl

(D) https://orcid.org/0000-0002-2614-7356

\section{Carmen Lissette Veloso Ramos}

Universidad de Concepción, Departamento de Gestión Empresarial Juan Antonio Coloma 0201, 4440000, Los Ángeles, Bío-Bio, Chile carmenveloso@udec.cl

(D) https://orcid.org/0000-0001-9390-9974

\section{Carlos Leandro Delgado Fuentealba}

Universidad de Concepción, Escuela de Administración y Negocios Vicente Méndez 595, 3780000, Chillán, Nuble, Chile

cadelgado@udec.cl

(D) https://orcid.org/0000-0001-7656-3254

* Corresponding author

Peer review is responsible for acknowledging an article's potential contribution to the frontiers of scholarly knowledge on business or public administration. The authors are the ultimate responsible for the consistency of the theoretical references, the accurate report of empirical data, the personal perspectives, and the use of copyrighted material.

This content was evaluated using the double-blind peer review process. The disclosure of the reviewers' information on the first page is made only after concluding the evaluation process, and with the voluntary consent of the respective reviewers. 